Article

\title{
"My Electricity" Program Effectiveness Supporting the Development of PV Installation in Poland
}

\author{
Piotr Olczak ${ }^{1, *(\mathbb{D})}$, Dominik Kryzia ${ }^{1}$ (D), Dominika Matuszewska ${ }^{2}$ and anta Kuta $^{2}(\mathbb{D}$ \\ 1 Mineral and Energy Economy Research Institute, Polish Academy of Sciences, 31-261 Cracow, Poland; \\ kryzia@min-pan.krakow.pl \\ 2 Department of Energy and Fuels, AGH University of Science and Technology, 30-059 Cracow, Poland; \\ dommat@agh.edu.pl (D.M.); marta.kuta@agh.edu.pl (M.K.) \\ * Correspondence: olczak@min-pan.krakow.pl
}

Citation: Olczak, P.; Kryzia, D.; Matuszewska, D.; Kuta, M. "My Electricity" Program Effectiveness Supporting the Development of PV Installation in Poland. Energies 2021, 14, 231. https://doi.org/10.3390/en 14010231

Received: 14 November 2020 Accepted: 30 December 2020 Published: 4 January 2021

Publisher's Note: MDPI stays neutral with regard to jurisdictional clai$\mathrm{ms}$ in published maps and institutional affiliations.

Copyright: (C) 2021 by the authors. Licensee MDPI, Basel, Switzerland. This article is an open access article distributed under the terms and conditions of the Creative Commons Attribution (CC BY) license (https:// creativecommons.org/licenses/by/ $4.0 /)$.

\begin{abstract}
There are a lot of studies that show the legitimacy of subsidizing renewable energy; however, some mechanisms are defective, and there are problems with the appropriate allocation of funds. Therefore, this paper aims to look at the situation of allocating funds to photovoltaics (PV) micro-installations in Poland through the "My Electricity" program. The article presents the results of analyses aimed at identifying inequalities between provinces in the use of funds available under the "My Electricity" program and verifying whether these inequalities are getting worse and whether the intensity of support should not be territorially conditioned in terms of maximization an electricity production. As part of two editions of the "My Electricity" program (until 1 August 2020), over 64,000 PV micro-installations were created with an average power of approximately $5.7 \mathrm{kWp}$. The total installed PV capacity was 367.1 MWp (1st edition: 159.3 MWp, 2nd edition: 207.8 MWp). Financial resources (as a whole), in the second edition of "My Electricity" program, were distributed better than in the first edition. In the first edition, as much as $7.60 \%$ of funds were allocated inefficiently; in the second edition, it was only $3.88 \%$. Allocation surpluses occur in provinces where the average disposable income is low and where there are a small number of households. There is a potential to introduce a territorial project selection criteria. The analysis shows that the criteria should promote provinces with higher disposable income and a larger number of households.
\end{abstract}

Keywords: photovoltaics; renewable energy sources; renewable energy; "My Electricity"; renewable energy policy; Poland; “Mój Prąd”; grant; renewable energy grants; renewable energy support

\section{Introduction}

In climate policy, renewable energy has become the main contributor to mitigating climate change by reducing dependence on fossil fuels and carbon dioxide $\left(\mathrm{CO}_{2}\right)$ emissions However, public policy aimed at supporting the production of energy from renewable sources (RES) has largely focused on encouraging investments in technologies using wind and solar resources, which has thus led to the recent increase in the capacity of installations supplied by these energy sources [1,2]. Moreover, many premises indicate that such a climate policy will be promoted in the future [3,4]. However, designing a renewable energy policy in an efficient, environmentally friendly, and socially equitable way requires an understanding of the impact of individual measures (support programs, subsidies, tax breaks, etc.) on the renewable energy market itself. Renewable energy growth in the energy mix usually has a twofold impact on the electricity market. Firstly, replacing conventional fossil technologies with generation from renewable sources leads to a reduction in $\mathrm{CO}_{2}$ emissions in energy production (the so-called exchange effect). Secondly, there is a price effect by pushing producers with high marginal costs out of the market and a decline in the wholesale electricity price (which reduces the profits of energy producers using conventional energy technologies). Meanwhile, the consumers are in an ambivalent position-on the one hand, they can benefit from lower energy prices, and on the other 
hand, they face higher costs to the extent that renewable energy subsidies are refinanced by taxes. In the light of this, it seems extremely important to properly allocate aid funds in RES by specifying the criteria determining the intensity of support $[2,5]$.

There is a lot of research about analyzing the policy support program for renewable electricity considering effective methods of promoting renewables, determining the intensity of support, and optimizing the distribution of financial support in relation to the effects they generate. For example, Nicolini and Tavoni [6], in their work, analyzed the influence of renewable energy support on promoting those technologies in France, Germany, Italy, the United Kingdom, and Spain, over the period 2000-2010. The analysis indicated that policy support positively affects the development of RES in the short and long term. However, in the short run, the feed-in tariff is more effective than the tradable green certificates mechanism in adopting renewable energy technologies. These studies are consistent with the results obtained by Dong [7], but his research focused only on the development of wind energy in Germany. Based on 92 renewable energy enterprises, Yang X. et al. [8] show that the government subsidies have a positive threshold effect on the level of investment in renewable energy in China. Their results show that Research \& Development support and further technological changes are key factors in accelerating the widespread use of solar photovoltaics. The research showed that the tax incentives have a more significant impact on renewable energy investment than monetary subsidies. In addition, it has been shown that government subsidies are the main force supporting the development of medium, small, and micro renewable energy enterprises; therefore, it should focus on subsidizing these entities. Niesten et al. [9] research focuses on who uses support programs in renewable energy, based on the example of investments in onshore wind energy in the Netherlands. These analyses show the trends among people investing in wind energy as well as which mechanisms affect the size of investments and can indirectly be the starting point for activating individual groups of investors by creating financial support packages for their needs. Benalcazar et al. [10] analyzed the impact of different national support policies on renewable energy systems and hybrid micro-grid systems. The influence of weather conditions (wind speed and insolation) on the power of individual units of distributed generation was investigated. The authors showed that the final design of microgrid systems for electrifying rural areas depends on the amount of the capital subsidies as well as fuel prices variations. Lekavicius et al. [11] examine the impact of investment subsidies on the installation of renewable energy technologies that cover a large part of the investment costs in Lithuania and thus play an important role in household energy decisions. Although the analyzed support is energy-efficient, it increases social inequalities by promoting higher-income households. Thus, the subsidies spent in this way do not contribute to reducing the phenomenon of energy poverty due to the low investment capacity of the poorest households. A flat distribution of benefits could be achieved by considering the situation of households with lower income and taking into account other affordability issues. In addition, Kazak et al. [12] research shows that stimulating the energy transformation to create new and renovate existing renewable energy sources (RES) installations should be supported by allocating public financial support to achieve these goals. However, the results showed (for all sources) that there is no correlation between the high level of absorption of RES funds and the potential of energy production. The authors suggest that a similar study should be done in the context of each of the European Union member states. In contrast, the study by Bointner et al. [13] showed that the financing of renewable energy sources in the European Union takes place at the level of the Union (through the European Commission), as well as the member states themselves, with the latter spending more money on it. However, the European Commission allocates its funds more evenly between the various renewable energy sources than the member states themselves.

In light of greenhouse gas reduction, solar energy seems to be a very promising option $[14,15]$ and (together with other renewable energy resources) has a key role in mitigation global warming by $1.5{ }^{\circ} \mathrm{C}[16,17]$. However, the research shows numerous 
uncertainties and barriers connected with adopting solar technologies [18,19]. Considering only PV technologies, the most important hindrance is the financing of such installation and the uncertainty about the return on investment costs [14,20]. Vasseur and Kemp [21] showed that the perceived net cost of PV is strongly correlated with the choice to adopt (or not) of the technology that was analyzed. In addition, other studies showed that the cost is an important barrier to the adoption of PV installation and that some financial solutions provided by the government can lead to a significant increase in PV installations [22]. However, many solutions emphasize the importance of the optimal distribution of financing in relation to the effects they generate. Mundaca and Samahita [23] considered factors that influence the (non-)adoption of PV installation in the case of Sweden. The results show that both subsidies and peer effects are important factors influencing the likelihood of solar PV adoption. In addition, the work of Myojo and Ohashi [24] provided an empirical framework to assess the role of consumer subsidies in residential solar PV installations in Japan. Sue and Yoon [25] investigate how the subsidy policy influences the growth of investments in PV installations on the example of Korea. Their study shows that productivity growth is influenced by factors such as the total amount of the subsidy budget, interest rates, insolation, and land prices in each region. Interestingly, it has been shown that maximizing the installed capacity with the same subsidy budget is possible with the transition from a single subsidy for each region to a subsidized one depending on the characteristics of a given region. Balibrea-Iniesta [26] evaluated the subsidies production of electricity from photovoltaic installation with capacity greater than $100 \mathrm{~kW}$ installed in France. The evaluation shows that the subsidy budget should be increased to be able to develop large-scale installations. Sampedro et al. [27] show how the relocation of fossil fuel subsidies (FFS) to promote solar photovoltaics on the roof would reduce $\mathrm{CO}_{2}$ emissions. It has been estimated that such action would reduce $\mathrm{CO}_{2}$ emissions to $2.2 \%$ by 2030 , and although this may not be the answer to all problems related to mitigating global warming, it can significantly contribute to promoting renewable energy and reducing environmental pollution without additional costs for the government (with only the transfer of funds from the FFS to RES). Torani K. et al. [28] in their work examined the prospects of solar photovoltaics (PV) in the residential and commercial sector in terms of the price of electricity and cost of solar. The developed stochastic dynamic model of adaptation solar PV showed that within 30 years, there will be a prevalent shift toward solar PV technologies both in residential and commercial sector. The result indicate that subsides and carbon price policies have little effect in accelerating adoption, and thus, an accelerating adoption may occur irrespective of these two factors.

Most of the studies discussed show the legitimacy of subsidizing renewable energy; however, some mechanisms are defective, and there are problems with the appropriate allocation of funds. Therefore, this paper aims to look at the situation of allocating funds to PV micro-installations in Poland. The article presents the results of analyses aimed at identifying inequalities between provinces in the use of funds available under the "My Electricity" program and verifying whether these inequalities are getting worse and whether the intensity of support should not be territorially conditioned, i.e., depend on the province where the project will be implemented.

Poland has average values of insolation in Europe, which in individual provinces are in the range from 900 to $1150 \mathrm{kWh} / \mathrm{m}^{2} /$ year (according to the Typical Meteorological Year) $[29,30]$. The differences in insolation occurring in individual provinces lead to a thesis that the share of projects located in southern voivodships should be greater than those located in northern Polish provinces, because the greater value of insolation makes the installation more energy-productive and economically effective. In this context, the question arises as to whether this issue should not determine the intensity of support. The economic efficiency of the installation is also influenced by its size, which is related to the effects of scale. Therefore, the power of the installation may also determine the intensity of support in addition to insolation (availability of solar energy). It is possible to estimate what the support intensity should be in individual voivodships in order to use 
the funds available under the "My Electricity" program most effectively. For this purpose, a mathematical model has been built, which has been used to optimize the use of subsidies financed under the "My Electricity" program. Figure 1 shows the annual insolation for each province and the total installed capacity in the "My Electricity" program until 1 August 2020 (according to the approved ranking lists).

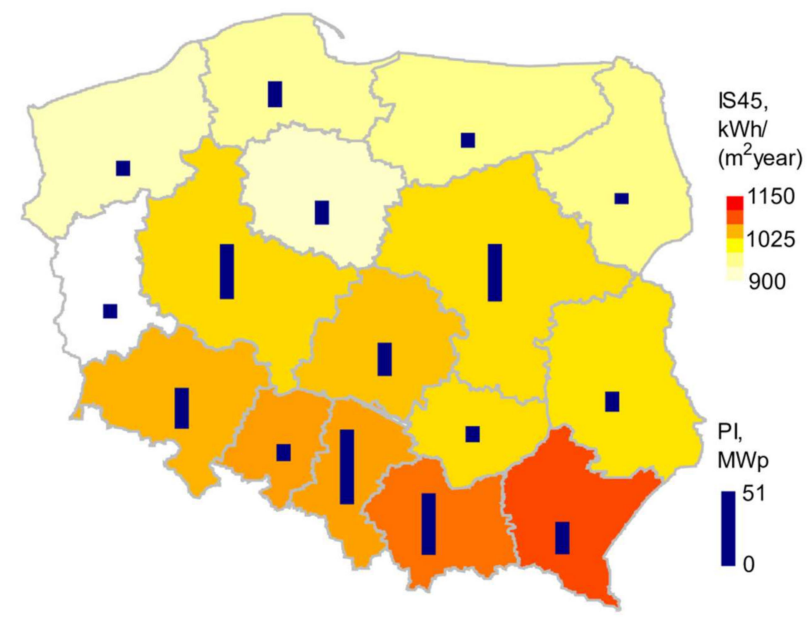

Figure 1. Insolation in Poland (for surface with tilt angle $=45^{\circ}$ and south faced) and total photovoltaics (PV) installation power (Table 1. August 2020) [29,31].

Table 1. Average and standard deviation for PV installation power per province.

\begin{tabular}{|c|c|c|c|c|c|}
\hline \multirow{2}{*}{ Province } & \multicolumn{3}{|c|}{ Average PV Power, kWp } & \multicolumn{2}{|c|}{ Standard Deviation, $\mathrm{kWp}$} \\
\hline & 1st Edition & 2nd Edition & $1 \& 2$ & 1st Edition & 2nd Edition \\
\hline Lower Silesia & 5.91 & 6.12 & 6.03 & 2.12 & 2.12 \\
\hline Kuyavian-Pomeranian & 5.91 & 6.01 & 5.97 & 2.20 & 2.23 \\
\hline Lubelskie & 5.35 & 5.28 & 5.32 & 2.03 & 2.05 \\
\hline Lubuskie & 5.95 & 6.20 & 6.10 & 2.10 & 2.12 \\
\hline Łódzkie & 5.96 & 6.08 & 6.02 & 2.18 & 2.21 \\
\hline Lesser Poland & 5.40 & 5.60 & 5.52 & 1.84 & 1.89 \\
\hline Masowian & 5.59 & 5.51 & 5.55 & 1.99 & 1.94 \\
\hline Opolskie & 6.13 & 6.38 & 6.27 & 1.98 & 1.07 \\
\hline Podkarpackie & 4.80 & 4.87 & 4.84 & 2.06 & 2.17 \\
\hline Podlaskie & 5.32 & 5.39 & 5.35 & 1.62 & 1.63 \\
\hline Pomeranian & 5.64 & 5.75 & 5.71 & 1.95 & 2.07 \\
\hline Silesian & 5.66 & 5.75 & 5.71 & 2.05 & 2.17 \\
\hline Świętokrzyskie & 5.08 & 5.15 & 5.11 & 2.01 & 2.06 \\
\hline Warmian-Masurian & 5.63 & 5.90 & 5.79 & 1.91 & 2.04 \\
\hline Greater Poland & 5.53 & 5.67 & 5.62 & 2.09 & 2.20 \\
\hline West Pomeranian & 5.82 & 5.82 & 5.82 & 1.94 & 2.06 \\
\hline
\end{tabular}

Color agenda: green—the highest value, red—-the lower value. Source: own study.

The paper is structured as follows. In Section 2, the data about the subsidiary program "My Electricity" for co-financing photovoltaic micro-installation in households in Poland is presented. The data are collected for two editions of the "My Electricity" program and are given for different provinces in Poland. In addition, the data about the average yearly insolation for a $45^{\circ}$ tilted surface south faced, average income in a household and the number of households in each of the voivodships is shown. Section 3 focuses on analysis and calculations, including the average power of PV installations and the average value of subsidies in each of the analysed provinces. In Section 4, an analysis of the subsidy program effectiveness is carried out in order to assess whether the funds transferred under the subsidy are optimally distributed in relation to the effects generated by the "My Electricity" 
program. For this purpose, data analyses have been carried out and a mathematical model has been built, using the statistical method of multiple regression allowing describing the covariance of several variables by fitting functions to them. The total power of PV installations (which received co-financing) in individual provinces has been assumed as the dependent variable. The explanatory variables have been the total number of households, the value of subsidies in the first edition of the "My Electricity" program, the average insolation, and the average disposable income in a household (analyzed at the province level). Additionally, the results of the analysis have been discussed. Finally, Section 5 discusses the economic and ecological implications of the "My Electricity" program on provinces in Poland, and conclusions are raised.

\section{Data}

The data available on the website of the PV micro-installations co-financing program "My Electricity" have been used for the purpose of this research (https://mojprad.gov. $\mathrm{pl})$. The available data included the following information: name, surname, province, installation capacity ( $\mathrm{kWp}$ ), subsidy (PLN), rate (on a scale of 1 to 4 points).

In the first edition of the "My Electricity" program, there were 28,437 submitted and approved applications, and in the second edition, there were 35,914 applications (as of 1 August 2020). The summary of applications numbers divided into provinces and program editions is presented in Figure 2a.

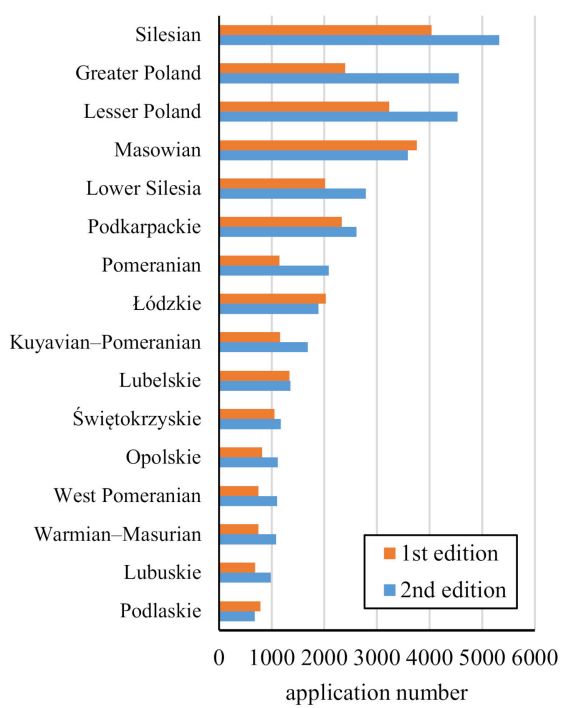

(a)

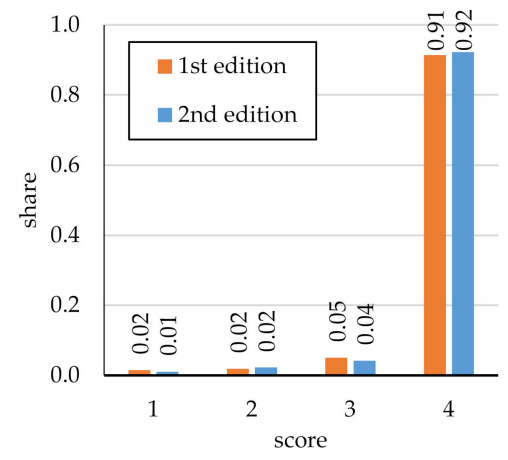

(b)

Figure 2. (a) Number of applications accepted in two editions of the "My Electricity" program (applications accepted until 1 August 2020) [31]; (b) Share of PV installations with a certain number of points among installations supported by both editions of the "My Electricity" program (applications accepted until 1 August 2020).

In both editions, the largest number of accepted applications came from the Silesian province. The lowest number of applications in the first edition was submitted in the Lubuskie province, and in the second edition, the lowest number of applications was submitted in the Podlasie province.

The information published as part of the ranking lists includes the number of points awarded depending on the installation unit price, which is expressed in PLN $/ \mathrm{kWp}$. When this price is lower than PLN 6000/kWp (1333 EUR/kWp, 1 EUR = 4.5 PLN), the evaluated application received 4 points. When the unit price was higher, a correspondingly smaller number of points were awarded (minimum 1). The vast majority (over 91\%) of applications received 4 points—see Figure $2 b$. 
The province with the highest score in the first edition was Opolskie: 3.91 (the average number of points awarded), and the province with the lowest province was Pomeranian: 3.79. In turn, in the second edition, the province with the highest average number of points awarded was Lubelskie with 3.92, and that with the lowest average number of points was Świętokrzyskie Province with 3.78. For both editions of the program, the Lubelskie province achieved the highest average number of points awarded: 3.91, and Pomeranian Province had the lowest: 3.80. Due to the over $90 \%$ share of applications with four points awarded, this issue was not analyzed in the following chapters. Some disproportions can be justified by the differences in the contracting price typical for each province [32], the size of the competition among assembly companies, as well as the size of installations expressed in kWp (Table 1).

The analysis is also based on the following data (for each province):

- Number of households, published by the Central Statistical Office [32].

- Average insolation as statistical climatic data for the area of Poland available on the archival website of the Ministry of Investment and Development [29].

- Value of disposable income published by the Central Statistical Office [33].

The numerical values for the above-mentioned data are presented in Table 2.

Table 2. The number of applications submitted in the second edition of the "My Electricity" program, the number of households (including in rural areas), the average insolation, and the value of disposable income in individual provinces.

\begin{tabular}{|c|c|c|c|c|c|}
\hline \multirow{2}{*}{ Province } & \multicolumn{2}{|c|}{ No. of Households, Thousand } & \multirow{2}{*}{$\begin{array}{l}\text { Number of } \\
\text { Applications }\end{array}$} & \multirow{2}{*}{$\begin{array}{c}\text { IS45 } \\
\mathrm{kWh} / \mathrm{m}^{2} / \text { year }\end{array}$} & \multirow{2}{*}{$\begin{array}{c}\text { DR } \\
\text { PLN/month }\end{array}$} \\
\hline & Total & Rural & & & \\
\hline Lower Silesia & 1100 & 275 & 4804 & 1086.1 & 5311 \\
\hline Kuyavian-Pomeranian & 729 & 239 & 2842 & 930.3 & 4641 \\
\hline Lubelskie & 742 & 356 & 2694 & 1049.8 & 4602 \\
\hline Lubuskie & 365 & 115 & 1655 & 891.9 & 4605 \\
\hline Łódzkie & 944 & 282 & 3919 & 1074.2 & 4864 \\
\hline Lesser Poland & 1080 & 454 & 7758 & 1130.5 & 5156 \\
\hline Masowian & 1943 & 557 & 7346 & 1055.3 & 6159 \\
\hline Opolskie & 354 & 147 & 1931 & 1101.4 & 4788 \\
\hline Podkarpackie & 649 & 336 & 4941 & 1151.6 & 4463 \\
\hline Podlaskie & 417 & 145 & 1455 & 974.8 & 4645 \\
\hline Pomeranian & 806 & 224 & 3231 & 962.8 & 5290 \\
\hline Silesian & 1728 & 315 & 9353 & 1098.4 & 5200 \\
\hline Świętokrzyskie & 429 & 208 & 2223 & 1054.8 & 4529 \\
\hline Warmian-Masurian & 516 & 182 & 1827 & 973.6 & 4376 \\
\hline Greater Poland & 1129 & 418 & 6946 & 1057.3 & 4756 \\
\hline West Pomeranian & 639 & 170 & 1852 & 942.8 & 4872 \\
\hline Poland & 13,568 & 4421 & 64,777 & & \\
\hline
\end{tabular}

IS45-average yearly insolation for $45^{\circ}$ tilted surface south faced. DR-average disposable income in a household in 2018. Source: own study based on $[29,31-33]$.

\section{Analysis and Calculations}

The total installed PV capacity for both editions of the program was 367.1 MWp (1st edition: 159.3 MWp, 2nd edition: 207.8 MWp).

In both editions, the average PV installation power of $5.69 \mathrm{kWp}$ was achieved $(5.57 \mathrm{kWp}$ in the first edition and $5.79 \mathrm{kWp}$ in the second edition). The standard deviation for the data from the first edition has a value of $2.01 \mathrm{kWp}$, and that for the second edition has a value of $2.07 \mathrm{kWp}$. The curves presenting the occurrence of specific installations sizes for both editions and also the maximum unit grant amount are presented in Figure 3. 


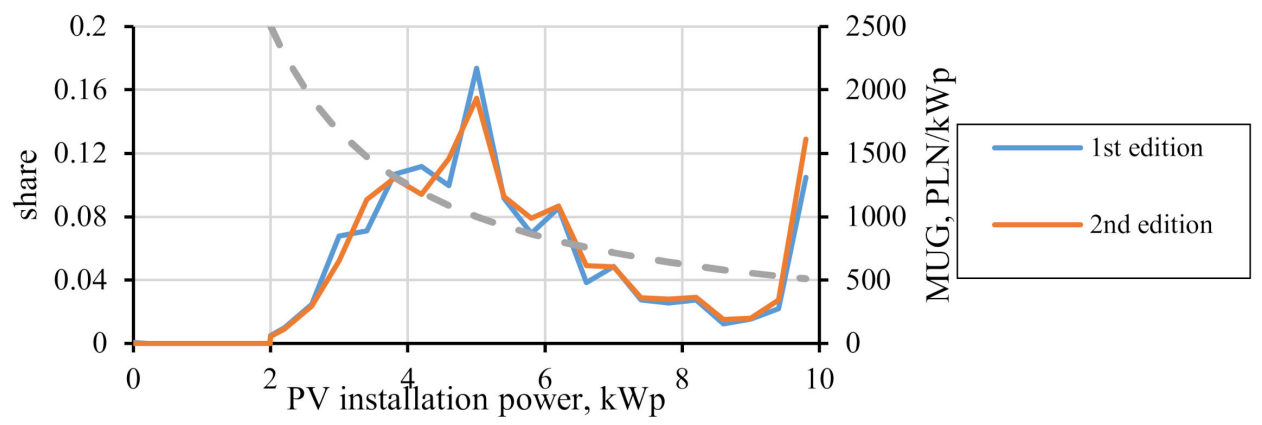

Figure 3. Share of PV installations of a certain capacity among installations installed in both editions of "My Electricity" program (applications accepted until 1 August 2020). MUG-maximum unit grant amount per $\mathrm{kWp}$.

The average capacity for installations in the provinces scale are presented in Table 1.

In total, PLN 323.45 million was spent under the program, which is $32 \%$ of the entire program budget, amounting to PLN 1 billion. The average subsidy to the $\mathrm{kWp}$ amounted to PLN 881. The results for individual provinces are presented in Table 3.

Table 3. The average value of the subsidy and standard deviations within the subsidy to $\mathrm{kWp}$.

\begin{tabular}{cccccc}
\hline \multirow{2}{*}{ Province } & \multicolumn{2}{c}{ Average Unit Value of the Subsidy PLN/kWp } & \multicolumn{2}{c}{ Standard Deviation, PLN/kWp } \\
\cline { 2 - 6 } & 1st Edition & 2nd Edition & 1\&2 & 1st Edition & 2nd Edition \\
\hline Lower Silesia & 839.4 & 816.6 & 826.0 & 334.8 & 347.4 \\
Kuyavian-Pomeranian & 836.6 & 830.4 & 832.9 & 361.5 & 382.7 \\
Lubelskie & 924.4 & 945.4 & 934.9 & 387.8 & 381.0 \\
Lubuskie & 834.4 & 805.3 & 816.9 & 321.8 & 361.2 \\
Łódzkie & 831.5 & 820.3 & 826.0 & 351.9 & 333.6 \\
Lesser Poland & 922.3 & 891.8 & 904.2 & 324.5 & 355.5 \\
Masowian & 887.7 & 906.6 & 896.9 & 344.6 & 315.4 \\
Opolskie & 810.3 & 783.6 & 794.7 & 318.4 & 362.2 \\
Podkarpackie & 1032.5 & 1023.6 & 1027.7 & 340.1 & 377.3 \\
Podlaskie & 927.0 & 928.3 & 927.6 & 377.1 & 353.9 \\
Pomeranian & 873.3 & 867.7 & 869.6 & 370.0 & 347.3 \\
Silesian & 878.5 & 869.1 & 873.2 & 351.5 & 391.0 \\
Swiętokrzyskie & 974.8 & 970.0 & 972.3 & 388.5 & 378.8 \\
Warmian-Masurian & 876.8 & 845.8 & 858.1 & 362.4 & 346.8 \\
Greater Poland & 893.6 & 880.0 & 884.6 & 354.1 & 340.7 \\
West Pomeranian & 847.4 & 858.9 & 854.2 & 356.1 & \\
\hline
\end{tabular}

Color agenda: green — the highest value, red—the lower value. Source: own study.

As shown in Table 3, the highest average subsidies to power (expressed in $\mathrm{kWp}$ ) were in Podkarpackie province and the lowest were in the Opolskie province. The difference in values of the unit subsidy between these provinces is over PLN 200/kWp, which is more than $20 \%$ of the average subsidy in the whole country. These differences are mainly due to the average installed capacity under the program in provinces (Table 1) and the maximum amount of the subsidy, which is PLN 5000 (Figure 3-MUG).

Similarly to the presented conclusions from the work of Olczak et al. [34], the relationship between the installed capacity and the number of provinces residents has been presented-see Figure 4. 


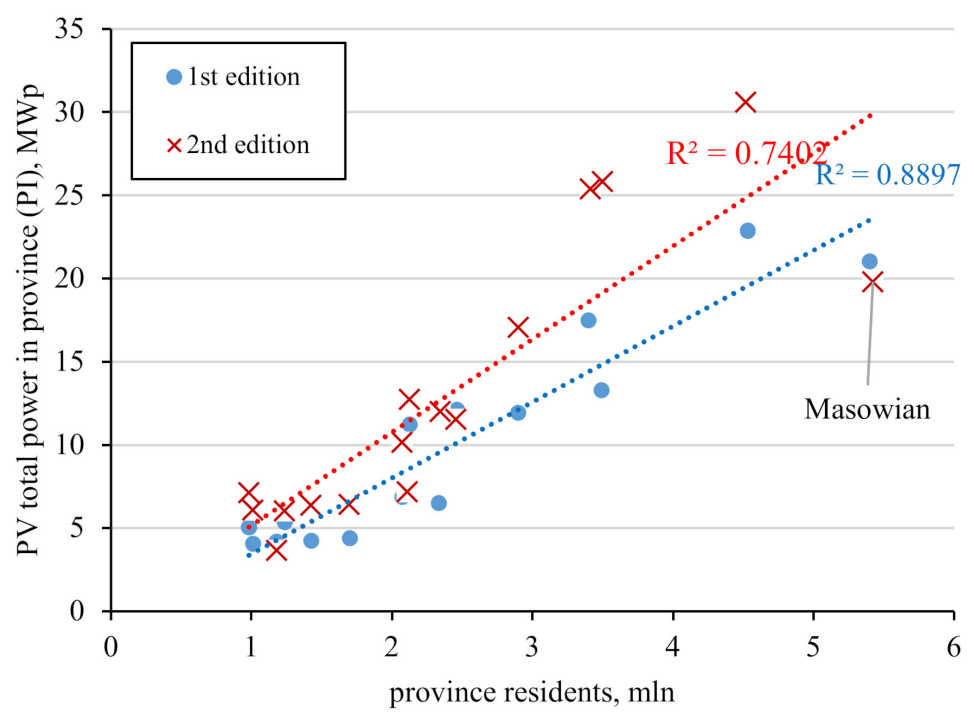

Figure 4. Dependence of installed capacity in the province on the number of residents in the province in both editions of the "My Electricity" program (applications accepted until 1 August 2020) [31].

The value of the $\mathrm{R}^{2}$ coefficient (Figure 4 ) for second edition is much higher, without taking into account the Masowian province (point 5.42 million; 19.77 MWp in Figure 4), which is 0.91 . In case of the first edition, eliminating from the calculation of the $R^{2}$ coefficient the above-mentioned province practically does not change the result. Due to the high correlation shown in Figure 4, the power index expressed in Wp per resident (PPI) [7] was calculated according to the formula below. The results are listed in Table 4 .

$$
P P I(\text { prov. })=\frac{P I(\text { prov. })}{L M(\text { prov. })}, \frac{W p}{\text { inhab. }}
$$

where

PI-power of installations installed in the province;

$L-$ number of residents in the province.

Table 4. Results of calculations of the PPI index (PV power per resident) for each province.

\begin{tabular}{cccc}
\hline \multirow{2}{*}{ Province } & & PPI, Wp/inhab. & \\
\cline { 2 - 4 } & 1st Edition & 2nd Edition & 1\&2 \\
\hline Lower Silesia & 4.11 & 5.88 & 9.99 \\
Kuyavian-Pomeranian & 3.29 & 4.89 & 8.18 \\
Lubelskie & 3.38 & 3.40 & 6.78 \\
Lubuskie & 4.06 & 5.99 & 10.05 \\
Łódzkie & 4.91 & 4.69 & 9.60 \\
Lesser Poland & 5.40 & 7.44 & 12.84 \\
Masowian & 3.89 & 3.65 & 7.53 \\
Opolskie & 5.08 & 7.22 & 12.30 \\
Podkarpackie & 5.26 & 5.98 & 11.24 \\
Podlaskie & 3.52 & 3.08 & 6.60 \\
Pomeranian & 2.77 & 5.12 & 7.89 \\
Silesian & 5.04 & 6.77 & 11.81 \\
Swiętokrzyskie & 4.30 & 4.89 & 9.19 \\
Warmian-Masurian & 2.95 & 4.47 & 7.42 \\
Greater Poland & 3.79 & 7.38 & 11.17 \\
West Pomeranian & 2.56 & 3.78 & 6.35 \\
\hline Poland & 4.12 & 5.41 & 9.54 \\
\hline
\end{tabular}

Color agenda: green—the highest value, red—-the lower value. Source: own study. 
Then, the number of applications (PV installations created under the "My Electricity" program) per 1000 households (Table 5) was calculated, as well as the installed capacity per household $(P P H)$ and per one rural household $(P P H C)$ :

$$
P P H(\text { prov. })=\frac{P I(\text { prov. })}{L G(\text { prov. })}, \frac{W p}{\text { household }}
$$

where

$L G$ - the number of households in the province.

$$
\text { PPHC(prov. })=\frac{P I(\text { prov. })}{L G W(\text { prov. })}, \frac{W p}{\text { rural household. }}
$$

where

$L G W$-number of rural households in the province.

Table 5. Comparison of the number of applications with the number of households in the province.

\begin{tabular}{ccccc}
\hline \multirow{2}{*}{ Province } & \multirow{2}{*}{$\begin{array}{c}\text { No. Applications/1000 } \\
\text { Households }\end{array}$} & \multirow{2}{*}{$\begin{array}{c}\text { No. Applications/1000 } \\
\text { Rural Households }\end{array}$} & PPH & PPHC \\
\cline { 4 - 5 } & 4.4 & 17.5 & 26.4 & Wp/Rural Households \\
\hline Lower Silesia & 3.9 & 11.9 & 23.3 & 105.3 \\
Kuyavian-Pomeranian & 3.6 & 7.6 & 19.3 & 71.0 \\
Lubelskie & 4.5 & 14.4 & 27.9 & 80.2 \\
Lubuskie & 4.2 & 13.9 & 25.0 & 83.8 \\
Łódzkie & 7.2 & 17.1 & 40.5 & 96.4 \\
Lesser Poland & 3.8 & 13.2 & 21.0 & 73.2 \\
Masowian & 5.5 & 13.2 & 34.2 & 82.6 \\
Opolskie & 7.6 & 14.7 & 36.9 & 71.3 \\
Podkarpackie & 3.5 & 10.0 & 18.7 & 53.7 \\
Podlaskie & 4.0 & 14.5 & 22.9 & 82.6 \\
Pomeranian & 5.4 & 29.7 & 30.9 & 169.7 \\
Silesian & 5.2 & 10.7 & 26.5 & 54.6 \\
Swiętokrzyskie & 3.5 & 10.1 & 20.5 & 58.2 \\
Warmian-Masurian & 6.2 & 16.6 & 34.6 & 93.4 \\
Greater Poland & 2.9 & 10.9 & 16.9 & 63.6 \\
West Pomeranian & 4.8 & 14.7 & 27.0 & 82.8 \\
\hline Poland & & & \\
\hline
\end{tabular}

Color agenda: green—the highest value, red—the lower value. Source: own study.

The lowest ratio of the installations number per 1000 households (PPH) has been achieved in the West Pomeranian province, which is 2.9 , and the highest was in the Podkarpackie province, which is 7.6; nationwide, it is 4.8. Taking into account rural households, the lowest rate was achieved in the Lublin province, which is 7.6, and the highest was in the Silesian province, which is 29.7. The highest PPH index was achieved for the Lesser Poland province and the lowest was achieved for the West Pomeranian province. In turn, in the case of the PPHC indicator: the maximum was in the Silesian province, 169.7, and the lowest was in the Lublin province: 40.2.

\section{Analysis of the Effectiveness of the Subsidy Program 4.1. Analysis}

In order to assess whether the funds transferred as part of the subsidy are optimally distributed in relation to the effects generated by the "My Electricity" program, data analysis was carried out, and a mathematical model was built. For this purpose, the statistical method of multiple regression was used, allowing describing the covariance of several variables by fitting functions to them. The dependent variable was the sum of the capacity of PV installations (which received co-financing) in individual provinces. The explanatory variables were: the sum of the subsidies value in the first edition of the "My Electricity" program, the average value of a subsidy per household, the average insolation, 
and the average disposable income in a household. Values for the explanatory variables and the dependent variable were registered at the province level.

The collinearity of explanatory variables was examined. The results are shown in Figure 5. The collinearity of the variables was not found. The values of the Variance Inflation Factor (VIF) indicators for all analyzed variables are below 6. Due to the transformations of the variables used to build the model, structural multicollinearity was observed, but it does not affect the quality of forecasting the value of the explained variable, which is crucial for this work. Structural multicollinearity is important for the interpretation of model parameters; however, this issue has no significance for the research problem being solved.

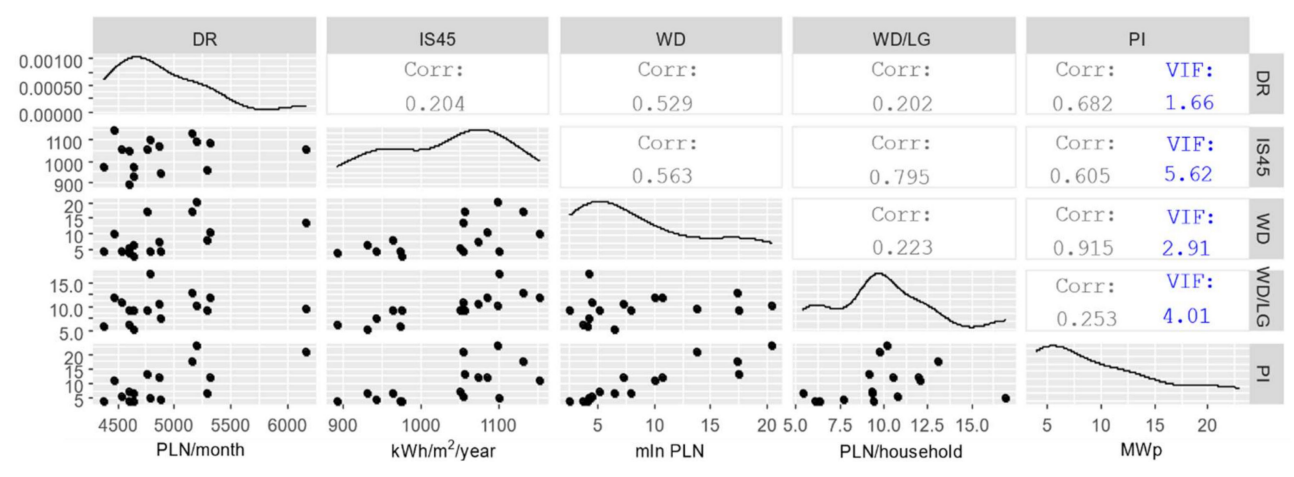

Figure 5. Correlation and collinearity of explanatory variables. VIF-Variance Inflation Factor.

Backward stepwise regression technique was used. The parameters for the model meeting the conditions of linear regression analysis are presented in Table 6. Table 7 presents the expected values of the dependent variable (installed capacity in individual provinces) and the values of the residual component.

Table 6. Regression model statistics.

\begin{tabular}{|c|c|c|c|c|c|c|}
\hline Variable & Coefficient & Standard Error & t Stat & $p$-Value & Lower 95\% & Upper $95 \%$ \\
\hline Intercept & 8255.22 & 1783.39 & 4.63 & 0.001238 & 4220.92 & $12,289.52$ \\
\hline DR IS45 & -0.002091 & 0.000538 & -3.887968 & 0.003686 & -0.003307 & -0.000874 \\
\hline WD IS45 & $1.963 \times 10^{-6}$ & $2.171 \times 10^{-7}$ & 9.045 & $8.195 \times 10^{-6}$ & $1.472 \times 10^{-6}$ & $2.455 \times 10^{-6}$ \\
\hline WD WD/LG & $-4.030 \times 10^{-8}$ & $1033 \times 10^{-8}$ & -3.902 & $3.610 \times 10^{-3}$ & $-6.366 \times 10^{-8}$ & $-1.693 \times 10^{-8}$ \\
\hline IS45 WD/LG & -0.001691 & 0.000305 & -5.537807 & 0.000362 & -0.002382 & -0.001000 \\
\hline DR IS45 WD & $-1.086 \times 10^{-10}$ & $3.164 \times 10^{-11}$ & -3.432 & $7.487 \times 10^{-3}$ & $-1.802 \times 10^{-10}$ & $-3.701 \times 10^{-11}$ \\
\hline \multirow[t]{2}{*}{ DR IS45 WD/LG } & $4.031 \times 10^{-7}$ & $7.869 \times 10^{-8}$ & 5.122 & $6.261 \times 10^{-4}$ & $2.251 \times 10^{-7}$ & $5.811 \times 10^{-7}$ \\
\hline & $\mathrm{df}$ & SS & MS & $\mathrm{F}$ & F materiality level & \\
\hline Regression & 6 & $586,011,923$ & $97,668,654$ & 1233.42 & $1.3534 \times 10^{-12}$ & \\
\hline Residual & 9 & 712,670 & 79,186 & & & \\
\hline Total & 15 & $586,724,592$ & & & & \\
\hline \multicolumn{7}{|c|}{ Regression Statistics } \\
\hline R multiples & 0.9994 & & & & & \\
\hline R square & 0.9988 & & & & & \\
\hline Adjusted R-squared & 0.9980 & & & & & \\
\hline Standard error & 281.40 & & & & & \\
\hline Trials & 16 & & & & & \\
\hline
\end{tabular}

Where: $L G$ —total number of households (in thousands); WD—the sum of the subsidies in the first edition of "My Electricity" program (PLN); IS45-average insolation calculated on a plane inclined to the horizontal at an angle of $45^{\circ}$ to the south $\left(\mathrm{kWh} / \mathrm{m}^{2} /\right.$ year); DR -average disposable income in a household in 2018 (PLN/month). Source: own study. 
Table 7. Predicted and residual values.

\begin{tabular}{cccc}
\hline Observation & Province & $\begin{array}{c}\text { Predicted Power of } \\
\text { PV Installation, kWp }\end{array}$ & Residual Values \\
\hline 1 & Lower Silesia & $12,035.86$ & -120.56 \\
2 & Kuyavian-Pomeranian & 6496.75 & 340.33 \\
3 & Lubelskie & 7486.66 & -319.94 \\
4 & Lubuskie & 4168.02 & -52.06 \\
5 & Eódzkie & $11,589.85$ & 509.02 \\
6 & Lesser Poland & $18,457.67$ & -87.28 \\
7 & Masowian & $20,940.80$ & 58.89 \\
8 & Opolskie & 4826.05 & 184.31 \\
9 & Podkarpackie & $11,105.44$ & 86.00 \\
10 & Podlaskie & 4464.94 & -309.10 \\
11 & Pomeranian & 6541.13 & -73.42 \\
12 & Silesian & $22,910.45$ & -80.00 \\
13 & Swiętokrzyskie & 5520.53 & -183.52 \\
14 & Warmian-Masurian & 4140.21 & 71.45 \\
15 & Greater Poland & $13,352.24$ & -110.21 \\
16 & West Pomeranian & 4275.45 & 86.10 \\
Sum & & $158,312.04$ & 0.00 \\
\hline
\end{tabular}

Color agenda: green—the highest value, red—the lower value. Source: own study.

The obtained results indicate that the constructed linear regression equation for the sum of installed PV power is correct because of the following:

(1) All explanatory variables were correctly captured in the linear regression model because the $p$-value of the Student's $t$-test for these variables was less than the significance level of 0.05 .

(2) The $p$-value of the $\mathrm{F}$ test calculated for the linear regression model was $1.3534 \times 10^{-12}$, and it is less than the significance level of 0.05 .

(3) The alignment factor $R^{2}$ was 0.9994 , which is very high, and it can be interpreted as follows: the exploitation factor $a$ was almost $100 \%$ as explained by the explanatory variables.

In addition, all formal requirements for classical linear regression analysis have been met:

(1) Explanatory variables are exogenous, which means that the values of the random term are not a function of the explanatory variables of the linear regression equation.

(2) There is a linear relationship between the explanatory variables and the dependent variable.

(3) The number of observations $n$ is greater than the number of structural parameters of the regression equation.

(4) Explanatory variables are non-random.

(5) The expected value of the random component is zero (Table 7).

(6) Values of the random component have a distribution close to the normal distribution $\mathrm{N}(0, \sigma)$, which has been confirmed by the Shapiro-Wilk statistical test, for residuals $\mathrm{W}=0.94051, p$-value $=0.3553$.

Knowing the power of PV installations in the province and the average annual insolation, it is possible to determine the theoretical annual electricity production.

The model has been used to determine the value of the subsidy for each province, which with a given value of subsidy (the sum of subsidies for the first edition of "My Electricity" program equal to 140 million PLN) will maximize the total value of the theoretical annual electricity production. In this way, it was determined how optimally the subsidy should be distributed to individual provinces, which thus provides grounds for determining the territorial criteria for selecting projects for co-financing under the "My Electricity" program. 


\subsection{Discussion of the Analysis Results}

The results of the analysis indicate that it is possible to improve the efficiency of using funds under the "My Electricity" program. The optimal distribution of subsidies allows increasing the theoretical (average annual) electricity production by $1.68 \%$ (first edition) and $3.26 \%$ (second edition).

Table 8 presents the value of subsidies for each province under the first and second editions of the "My Electricity" program. Table 9 presents the amount of subsidies for optimal variants (while maintaining the theoretical electricity production at the same level).

Table 8. The amount of the subsidy (WD), PLN.

\begin{tabular}{ccc}
\hline Province & 1st Edition & 2nd Edition \\
\hline Lower Silesia & $10,001,972$ & $13,933,500$ \\
Kuyavian-Pomeranian & $5,719,621$ & $8,413,577$ \\
Lubelskie & $6,624,871$ & $6,769,633$ \\
Lubuskie & $3,365,275$ & $4,879,917$ \\
Lódzkie & $10,043,978$ & $9,447,032$ \\
Lesser Poland & $16,086,613$ & $22,621,446$ \\
Masowian & $18,640,837$ & $17,930,030$ \\
Opolskie & $4,060,058$ & $5,561,416$ \\
Podkarpackie & $11,555,170$ & $13,021,064$ \\
Podlaskie & $3,852,511$ & $3,369,764$ \\
Pomeranian & $5,647,971$ & $10,403,653$ \\
Silesian & $20,057,216$ & $26,580,026$ \\
Świętokrzyskie & $5,202,406$ & $5,849,303$ \\
Warmian-Masurian & $3,692,589$ & $5,383,188$ \\
Greater Poland & $11,833,316$ & $22,712,726$ \\
West Pomeranian & $3,696,053$ & $5,509,597$
\end{tabular}

Table 9. The size of the subsidy calculated for optimal variants, PLN.

\begin{tabular}{ccc}
\hline Province & Optimal Variant for 1st Edition & Optimal Variant for 2nd Edition \\
\hline Lower Silesia & $13,402,642$ & $17,138,203$ \\
Kuyavian-Pomeranian & $4,118,127$ & $5,132,281$ \\
Lubelskie & $7,088,612$ & $9,003,611$ \\
Lubuskie & $2,389,345$ & $3,025,548$ \\
Łódzkie & $10,144,416$ & $12,942,433$ \\
Lesser Poland & $14,156,216$ & $18,323,371$ \\
Masowian & $19,200,057$ & $24,564,138$ \\
Opolskie & $6,090,087$ & $7,785,982$ \\
Podkarpackie & $7,857,514$ & $10,156,430$ \\
Podlaskie & $3,929,561$ & $5,088,344$ \\
Pomeranian & $7,737,720$ & $9,779,434$ \\
Silesian & $17,850,917$ & $22,858,816$ \\
Swiętokrzyskie & $4,682,165$ & $6,024,782$ \\
Warmian-Masurian & $3,249,478$ & $4,091,223$ \\
Greater Poland & $10,413,316$ & $13,400,508$ \\
West Pomeranian & $5,063,593$ & $6,391,132$ \\
Sum & $137,373,767$ & $175,706,238$ \\
\hline
\end{tabular}

Color agenda: green-the highest value, red-the lower value. Source: own study.

The analysis proved that it is possible to maintain the theoretical electricity production at the same level with a lower total value of the subsidy. In case of the first edition of the "My Electricity" program, it was possible to achieve the same theoretical electricity production with the subsidy value lower by $1.93 \%$, and in the second edition, it was possible with the value lower by $3.66 \%$. So, the funds in the second edition of the "My Electricity" program were distributed less effectively than those in the first edition.

When analyzing individual provinces in terms of the optimal level of subsidies, it was found that in case of first edition, the subsidy deficit (at the level of $7.20 \%$ of the total value of subsidies for edition 1) occurred in eight provinces. However, in the case of the 
second edition, the deficit of subsidies (at the level of $11.28 \%$ of the total value of subsidies for second edition) occurred in eight provinces. The surplus and deficits of subsidies in individual provinces are presented in Tables 10 and 11.

Table 10. Surpluses (positive value) and deficits (negative value) in subsidizing individual provinces, percentage. Value calculated in relation to the value of subsidies for individual provinces.

\begin{tabular}{ccc}
\hline Province & 1st Edition & 2nd Edition \\
\hline Lower Silesia & 34 & 23 \\
Kuyavian-Pomeranian & -28 & -39 \\
Lubelskie & 7 & 33 \\
Lubuskie & -29 & -38 \\
Łódzkie & 1 & 37 \\
Lesser Poland & -12 & -19 \\
Masowian & 3 & 37 \\
Opolskie & 50 & 40 \\
Podkarpackie & -32 & -22 \\
Podlaskie & 2 & 51 \\
Pomeranian & 37 & -6 \\
Silesian & -11 & -14 \\
Swiętokrzyskie & -10 & 3 \\
Warmian-Masurian & -12 & -24 \\
Greater Poland & -12 & -41 \\
West Pomeranian & 37 & 16 \\
\hline
\end{tabular}

Color agenda: green—the highest value, red—the lower value. Source: own study.

Table 11. Surpluses (positive value) and deficits (negative value) in subsidizing individual provinces, percentage. The value is calculated in relation to the total value of the subsidy (total for Poland).

\begin{tabular}{ccc}
\hline Province & 1st Edition & 2nd Edition \\
\hline Lower Silesia & -2.43 & -1.76 \\
Kuyavian-Pomeranian & 1.14 & 1.8 \\
Lubelskie & -0.33 & -1.22 \\
Lubuskie & 0.7 & 1.02 \\
Łódzkie & -0.07 & -1.92 \\
Lesser Poland & 1.38 & 2.36 \\
Masowian & -0.4 & -3.64 \\
Opolskie & -1.45 & -1.22 \\
Podkarpackie & 2.64 & 1.57 \\
Podlaskie & -0.06 & -0.94 \\
Pomeranian & -1.49 & 0.34 \\
Silesian & 1.58 & 2.04 \\
Świętokrzyskie & 0.37 & -0.1 \\
Warmian-Masurian & 0.32 & 0.71 \\
Greater Poland & 1.01 & 5.11 \\
West Pomeranian & -0.98 & -0.48 \\
\hline
\end{tabular}

Color agenda: green—the highest value, red-the lower value. Source: own study.

The total value of the surplus subsidies in the first edition was $9.13 \%$ of the total value of the subsidy allocated in the first edition. In the case of the second edition, this surplus was $14.94 \%$. These values can be equated with monetary value, which were incorrectly/ineffectively distributed. In case of the second edition, the inequality in the distribution of funds between provinces slightly increased compared to the first edition, as measured by the Herfindahl-Hirschman index (HHI). For the data from the first edition, the HHI index amounted 0.0861 , and for the second edition, it was 0.0870 . The HHI value for the optimal cash distribution in the first edition amounts 0.0839 , and in the second one, it was 0.0842 . Therefore, the optimal distribution of subsidies between provinces should be more uneven than it was in both editions. 
Correlation analysis showed that the values of surpluses and deficits correlate with the value of the average disposable (DR) income in individual provinces and subsidies value (WD) and average value of a subsidy per household (WD/LG) (Table 12).

Table 12. Values of correlation coefficients of subsidies surpluses/deficits in individual provinces and disposable income, the number of households and insolation, average value of a subsidy per household.

\begin{tabular}{ccc}
\hline Parameter & 1st Edition & 2nd Edition \\
\hline DR-average disposable income in a household & -0.35 & -0.40 \\
IS45-Insolation & 0.20 & 0.01 \\
WD-Subsidies value & 0.36 & 0.43 \\
LG-Number of households & 0.08 & -0.06 \\
WD/LG-Average value of a subsidy per household & -0.19 & -0.20 \\
\hline
\end{tabular}

Source: own study.

Allocation surpluses occur in provinces where the average disposable income is low, and deficits where the average income value is high. The situation is similar in the case of an average value of a subsidy per household: allocation surpluses occur in provinces with a low-value subsidy per household, and deficits occur with a large-value subsidy per household. The value of insolation (IS45) and number of households (LG) is very slightly correlated with surpluses/deficits of subsidies. It is also worth noting that allocation surpluses occur in voivodships where the amount of the subsidy granted was high. It is characteristic that in the second edition of the "My Electricity" program, the abovementioned correlations increased. This may indicate the saturation of the household sector with photovoltaic installations (an increase in the correlation coefficient for subsidies value (WD)), which means that less and less effective investments are undertaken (perhaps smaller and worse located). Thus, the importance of parameters such as average disposable income in a household is growing. Conclusions that can be drawn on this basis indicate that it would be reasonable to introduce a territorial project selection criterion that would allow increasing the allocation level in provinces with higher disposable income and in voivodships where the average value of a subsidy per household is high. Households with a higher value of disposable income invest in installations with a greater capacity, thanks to which the subsidy is better used due to the positive economies of scale, which is decreasing unit costs of purchasing PV installations along with the increase in the capacity of PV installations. Although the average value of subsidies per household (WD/LG) is poorly correlated with subsidies surpluses/deficits in individual provinces (the value of the correlation coefficient is around -0.2), the nature of this relationship is surprising and difficult to explain. It most probably results from social conditions (education, imitation, territorial, and social segmentation), which cause the "snowball effect". This issue requires in-depth research.

\section{Summary}

As part of two editions of the "My Electricity" program (until 1 August 2020), over 64,000 PV micro-installations were created, with an average power of approximately $5.7 \mathrm{kWp}$. The total installed PV capacity was 367.1 MWp (1st edition: 159.3 MWp. 2nd edition: 207.8 MWp).

The highest subsidies to the $\mathrm{kWp}$ were achieved in the Podkarpackie province with practically the highest productivity (which brings additional benefits for the household). On the one hand, every PLN spent in the Podkarpackie province contributes to higher ecological and economic effects than, for example, in the northern provinces. This work has shown that a different way of distributing the subsidy (other criteria) would contribute to the same effects in terms of energy productivity, generating savings in the form of PLN 2.7 million in the case of the first edition and PLN 6.7 million in the case of the second edition of the program. 
Financial resources (as a whole) in the second edition of the "My Electricity" program were distributed worse than in the first edition. In the first edition, as much as $1.93 \%$ of funds were allocated inefficiently; in the second edition, it was only $3.66 \%$. However, if we analyze and compare each province, the inequality in the allocation of funds in the second edition increased in comparison to the first edition.

Allocation surpluses occur in provinces where the average disposable income is low and where there is a high value of subsidies per household.

There is a potential to introduce a territorial project selection criteria. The analysis shows that the criteria should promote provinces with higher disposable income and high-value household subsidies. However, the significance of the latter parameter should be clearly explained. The "My Electricity" program is coming to an end. In the future, research should be planned to take into account of the complete data for both editions of the program. Moreover, the research should be extended to the analysis of the optimal allocation of subsidies from the point of view of various parties, i.e., applicants, the state, and the society. The research results may be helpful in designing a new PV technology support program (in 2021).

Author Contributions: Conceptualization, P.O., D.M. and D.K.; methodology, P.O. and D.K.; software, P.O., D.M. and D.K.; validation, D.M. and M.K.; formal analysis, P.O., D.M. and D.K.; investigation, M.K.; resources, P.O. and D.M.; data curation, D.K. and M.K.; writing-original draft preparation, P.O., D.M., M.K. and D.K.; writing-review and editing, D.M. and M.K.; visualization, P.O.; supervision, P.O.; project administration, P.O. and M.K.; funding acquisition, P.O., D.M., M.K. and D.K. All authors have read and agreed to the published version of the manuscript.

Funding: This work was supported by AGH-University of Science and Technology number 16.16.210.476.

Conflicts of Interest: The authors declare no conflict of interest.

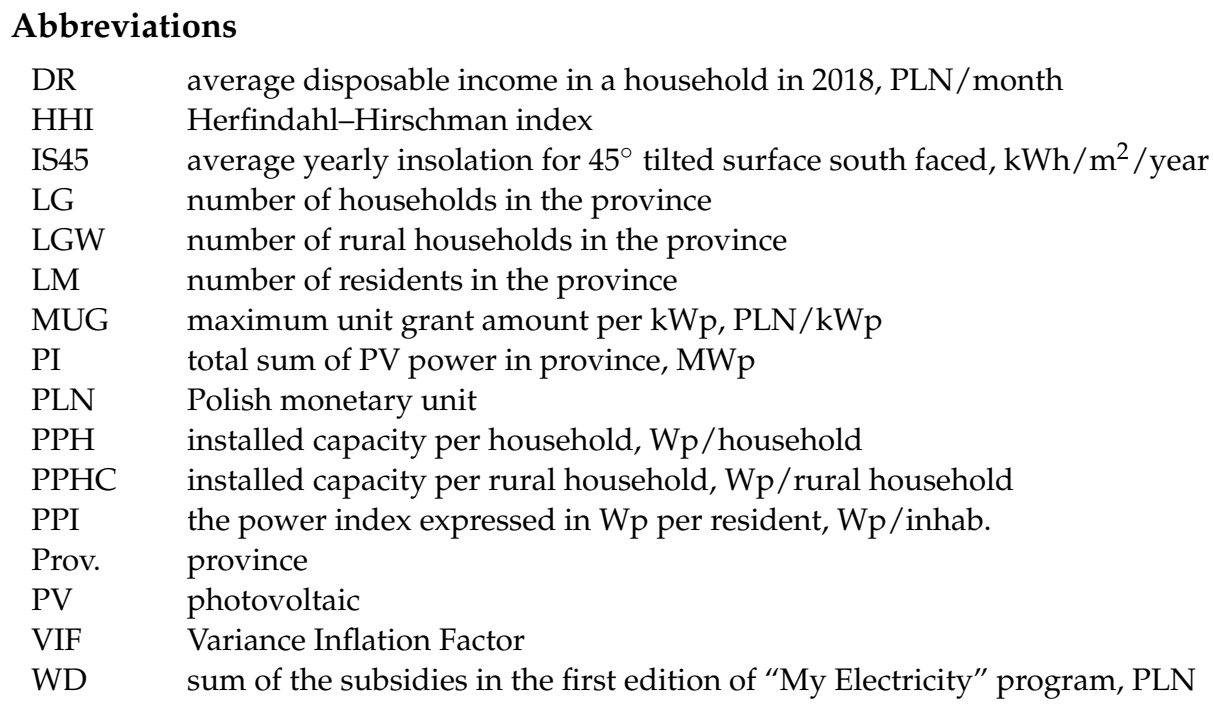

\section{References}

1. REN21 Renewables 2018 Global Status Report (Paris: REN21 Secretariat). Available online: http://www.ren21.net/gsr-2018/ (accessed on 12 November 2020).

2. Abrell, J.; Kosch, M.; Rausch, S. Carbon abatement with renewables: Evaluating wind and solar subsidies in Germany and Spain. J. Public Econ. 2019, 169, 172-202. [CrossRef]

3. Fischer, C.; Newell, R.G. Environmental and technology policies for climate mitigation. J. Environ. Econ. Manag. 2008, 55, 142-162. [CrossRef]

4. Meckling, J.; Sterner, T.; Wagner, G. Policy sequencing toward decarbonization. Nat. Energy 2017, 2, 918-922. [CrossRef]

5. Abrell, J.; Rausch, S.; Streitberger, C. The economics of renewable energy support. J. Public Econ. 2019, 176, 94-117. [CrossRef]

6. Nicolini, M.; Tavoni, M. Are renewable energy subsidies effective? Evidence from Europe. Renew. Sustain. Energy Rev. 2017, 74, 412-423. [CrossRef] 
7. Dong, C.G. Feed-in tariff vs. renewable portfolio standard: An empirical test of their relative effectiveness in promoting wind capacity development. Energy Policy 2012, 42, 476-485. [CrossRef]

8. Yang, X.; He, L.; Xia, Y.; Chen, Y. Effect of government subsidies on renewable energy investments: The threshold effect. Energy Policy 2019, 132, 156-166. [CrossRef]

9. Niesten, E.; Jolink, A.; Chappin, M. Investments in the Dutch onshore wind energy industry: A review of investor profiles and the impact of renewable energy subsidies. Renew. Sustain. Energy Rev. 2018, 81, 2519-2525. [CrossRef]

10. Benalcazar, P.; Suski, A.; Kamiński, J. The Effects of Capital and Energy Subsidies on the Optimal Design of Microgrid Systems. Energies 2020, 13, 955. [CrossRef]

11. Lekavičius, V.; Bobinaitè, V.; Galinis, A.; Pažèraitè, A. Distributional impacts of investment subsidies for residential energy technologies. Renew. Sustain. Energy Rev. 2020, 130, 109961. [CrossRef]

12. Kazak, J.K.; Kamińska, J.A.; Madej, R.; Bochenkiewicz, M. Where renewable energy sources funds are invested? spatial analysis of energy production potential and public support. Energies 2020, 13, 5551. [CrossRef]

13. Bointner, R.; Pezzutto, S.; Grilli, G.; Sparber, W. Financing innovations for the renewable energy transition in Europe. Energies 2016, 9, 990. [CrossRef]

14. Mitchell, C.; Sawin, J.L.; Pokharel, G.R.; Kammen, D.; Wang, Z.; Fifita, S.; Jaccard, M.; Langniss, O.; Lucas, H.; Nadai, A.; et al. Policy, Financing and Implementation. In Renewable Energy Sources and Climate Change Mitigation; Cambridge University Press: Cambridge, UK, 2011.

15. Jacobson, M.Z.; Delucchi, M.A.; Bauer, Z.A.F.; Goodman, S.C.; Chapman, W.E.; Cameron, M.A.; Bozonnat, C.; Chobadi, L.; Clonts, H.A.; Enevoldsen, P.; et al. 100\% Clean and Renewable Wind, Water, and Sunlight All-Sector Energy Roadmaps for 139 Countries of the World. Joule 2017, 1, 108-121. [CrossRef]

16. Arvizu, D.; Bruckner, T.; Chum, H.; Edenhofer, O.; Pichs-Madruga, R.; Sokona, Y.; Seyboth, K.; Eickemeier, P.; Matschoss, P.; Hansen, G.; et al. IPCC, 2011: Summary for Policymakers. In IPCC Special Report on Renewable Energy Sources and Climate Change Mitigation; IPCC: Geneva, Switzerland, 2011; ISBN 9789291691319.

17. Canales, F.A.; Jadwiszczak, P.; Jurasz, J.; Wdowikowski, M.; Ciapała, B.; Kaźmierczak, B. The impact of long-term changes in air temperature on renewable energy in Poland. Sci. Total Environ. 2020, 729, 138965. [CrossRef]

18. Rai, V.; Reeves, D.C.; Margolis, R. Overcoming barriers and uncertainties in the adoption of residential solar PV. Renew. Energy 2016, 89, 498-505. [CrossRef]

19. Sahu, B.K. A study on global solar PV energy developments and policies with special focus on the top ten solar PV power producing countries. Renew. Sustain. Energy Rev. 2015, 43, 621-634. [CrossRef]

20. Zelazna, A.; Gołębiowska, J.; Zdyb, A.; Pawłowski, A. A hybrid vs. on-grid photovoltaic system: Multicriteria analysis of environmental, economic, and technical aspects in life cycle perspective. Energies 2020, 15, 3978. [CrossRef]

21. Vasseur, V.; Kemp, R. The adoption of PV in the Netherlands: A statistical analysis of adoption factors. Renew. Sustain. Energy Rev. 2015, 41, 483-494. [CrossRef]

22. Faiers, A.; Neame, C. Consumer attitudes towards domestic solar power systems. Energy Policy 2006, 34, 1797-1806. [CrossRef]

23. Mundaca, L.; Samahita, M. What drives home solar PV uptake? Subsidies, peer effects and visibility in Sweden. Energy Res. Soc. Sci. 2020, 60, 101319. [CrossRef]

24. Myojo, S.; Ohashi, H. Effects of consumer subsidies for renewable energy on industry growth and social welfare: The case of solar photovoltaic systems in Japan. J. Jpn. Int. Econ. 2018, 48, 55-67. [CrossRef]

25. Suh, J.; Yoon, S.G. Maximizing solar PV dissemination under differential subsidy policy across regions. Energies 2020, 13, 2763. [CrossRef]

26. Balibrea-Iniesta, J. Economic analysis of renewable energy regulation in France: A case study for photovoltaic plants based on real options. Energies 2020, 13, 2760. [CrossRef]

27. Sampedro, J.; Arto, I.; González-Eguino, M. Implications of switching fossil fuel subsidies to solar: A case study for the European Union. Sustainability 2017, 10, 50. [CrossRef]

28. Torani, K.; Rausser, G.; Zilberman, D. Innovation subsidies versus consumer subsidies: A real options analysis of solar energy. Energy Policy 2016, 92, 255-269. [CrossRef]

29. Ministry of Development Typical Reference Year. Available online: https://www.gov.pl/web/fundusze-regiony/dane-doobliczen-energetycznych-budynkow (accessed on 18 December 2019).

30. Olczak, P.; Matuszewska, D.; Zabagło, J. The Comparison of Solar Energy Gaining Effectiveness between Flat Plate Collectors and Evacuated Tube Collectors with Heat Pipe: Case Study. Energies 2020, 13, 1829. [CrossRef]

31. NFOŚiGW Mój Prąd. Available online: https://mojprad.gov.pl/wyniki-1-naboru-2019/ (accessed on 7 April 2020).

32. CSO. National Census; Central Statistical Office: Warsaw, Poland, 2014.

33. CSO. Household Budget Survey in 2018; Central Statistical Office: Warsaw, Poland, 2019.

34. Olczak, P.; Matuszewska, D.; Kryzia, D. "Mój Prąd" as an example of the photovoltaic one off grant program in Poland. Energy Policy J. 2020, 23, 123-138. [CrossRef] 